\title{
Report on the chromosome numbers of four Carex taxa in Korea (Cyperaceae)
}

\author{
Kyong-Sook CHUNG* and Hyoung-Tak IM ${ }^{\mathbf{1}}$ \\ Department of Medicinal Plant Science, Jungwon University, Goesan 28024, Korea \\ ${ }^{1}$ Department of Division of Biological Science, Chonnam National University, Gwangju 61186, Korea \\ (Received 13 August 2019; Revised 18 September 2019; Accepted 23 September 2019)
}

\begin{abstract}
We report the meiotic chromosome numbers of four Carex taxa from Korean populations. Three are the first reports made on taxa from Korean populations: Carex appendiculata (Trautv. \& C. A. Mey.) Kük. ( $n=$ $\left.27_{\text {II }}\right)$, C. fernaldiana H. Lév. \& Vaniot $\left(n=33_{\text {II }}\right)$, and $C$. metallica H.Lév. $\left(n=15_{\text {II }}\right)$. Reports on the other species expand the range of variation in the chromosome number within a taxon, $C$. miyabei Franch. $\left(n=43_{\text {II }}, 44_{\text {II }}, 45_{\text {II }}\right)$. Carex L. (Cyperaceae) consists of more than 2,000 species worldwide and is the most species-rich genus in Korea. The species diversity in the genus has been hypothesized to be associated with the chromosome variation, but chromosome information pertaining to Korean Carex taxa is not well known. This report updates the chromosome number inventory on Korean Carex to 24 out of 180 taxa.
\end{abstract}

Keywords: Carex, chromosome number, Cyperaceae

Chromosome information has long been an interesting research topic to numerous natural scientists. Chromosome contains hereditary genomic information allowing us to understand functional, structural, genetic, and evolutionary features of organisms. Chromosome number information detects major genomic events such as aneuploidy and polyploidy and has been consistently investigated (Guerra, 2008; Rice et al., 2015). In plant systematics, cytotaxonomic, phylogenetic and speciation inferences of chromosome numbers have been appreciated throughout the vascular pant lineages (de Azkue and Martĩnez, 1990; Chung and Kim, 1997; McArthur and Sanderson, 1999; Windham and Yatskievych, 2003; Peruzzi et al., 2009; Rockinger et al., 2016).

In Carex L. diversity research, chromosomes have provided critical information in various levels of taxonomic and phylogenetic groups, dealing with taxonomic delimitation, gene flow, lineage divergence, and evolution rate related questions (Tanaka, 1948; Davies, 1956; Rothrock and Reznicek, 1996; Hoshino, 1981; Rothrock et al., 2009; Hipp et al., 2010; Chung et al., 2012; Escudero et al., 2012). The genus is the most species-rich group in the temperate zones with more than 2,000 species worldwide (Global Carex Group, 2015). As a holocentric chromosome group, chromosome number increase and/or decrease without DNA duplication and/or deletion events (agmatoploidy and symploidy) (Luceño and Guerra, 1996; Hipp et al., 2013) might cause relatively rapid speciation (Hipp et al., 2010; Chung et al., 2012; Escudero et al., 2012). Although chromosome information has been considered critical features for Carex diversity, chromosome numbers of about only 20 taxa out of 180 Korean taxa have been documented (Kim, 2006; Lee and Kim, 2008; Chung et al., 2013; Chung et al., 2016; Chung et al., 2017; Chung et al., 2018; Chung and $\operatorname{Im}, 2018)$.

In this study, we report meiotic chromosome numbers for four Carex species from Korean populations and discuss their taxonomic and cytological significances: C. miyabei Franch., C. metallica H. Lév., C. fernaldiana H. Lév. \& Vaniot, and $C$. appendiculata (Trautv. \& C. A. Mey.) Kük.

\section{Materials and Methods}

Spikes with unopened staminate flowers were fixed in March and/or April, and voucher specimens with fully mature perigynia were collected in May and/or June, either 2018 or 2019. The methods for chromosome observation were applied as described in Rothrock and Reznicek (1996) and Chung et

\footnotetext{
*Author for correspondence: kchung@jwu.ac.kr
} 
Table 1. Carex taxa investigated with voucher specimens and chromosome numbers.

\begin{tabular}{|c|c|c|c|}
\hline & Taxon (locality, voucher specimen) & $\begin{array}{l}\text { Chromosome } \\
\text { numbers counted, } \\
2 n(n)\end{array}$ & Previous counts, $2 n$ \\
\hline Sect. Carex & $\begin{array}{l}\text { Carex miyabei Franch. } \\
\text { Songdeok-ri, Goesan-gun, Chungcheongbuk-do, South Korea } \\
\text { (Chung 6077, } 7 \text { Jun 2019, KH) }\end{array}$ & $\begin{array}{c}86,88,90 \\
\left(n=43_{\mathrm{II}}, 44_{\mathrm{II}}, 45_{\mathrm{II}}\right)\end{array}$ & $\begin{array}{c}90 \text { (Tanaka, 1948) } \\
84 \text { (Chung et al., 2018) } \\
66,72 \text { (Chung and Im, 2018) }\end{array}$ \\
\hline Sect. Hymenochlaenae & $\begin{array}{l}\text { Carex metallica H. Lév. } \\
\text { Yongsu-ri, Hangyeong-myeon, Jeju-si, South Korea } \\
\text { (Chung 5150, } 1 \text { Jun 2018, KH) }\end{array}$ & $\begin{array}{c}30 \\
\left(n=15_{\mathrm{II}}\right)\end{array}$ & 30 (Hoshino et al., 2011) \\
\hline Sect. Mitratae & $\begin{array}{l}\text { Carex fernaldiana H. Lév. \& Vaniot } \\
\text { Surisan Mt., Anyang-si, Gyeonggi-do, South Korea } \\
\text { (Chung 6048-1, } 20 \text { May 2019, KH) }\end{array}$ & $\begin{array}{c}66 \\
\left(n=33_{\mathrm{II}}\right)\end{array}$ & $\begin{array}{c}67 \text { (Tanaka, 1948) } \\
\text { 66-74 (Hoshino et al., 2011) }\end{array}$ \\
\hline Sect. Phacocystis & $\begin{array}{l}\text { Carex appendiculata (Trautv. \& C. A. Mey.) Kük. } \\
\text { Yupyeong-ri, Nam-myeon, Jeongseon-gun, Gangwon-do, South Korea } \\
\text { (Chung 6070, } 19 \text { May 2019, KH) }\end{array}$ & $\begin{array}{c}54 \\
\left(n=27_{\mathrm{II}}\right)\end{array}$ & $\begin{array}{c}\text { c. } 80 \text { (Krogulevich, 1976) } \\
76 \text { (Zhukova and Petrovsky, 1976) }\end{array}$ \\
\hline
\end{tabular}

al. (2016). Fixed anthers in a fixing mixture of methanol, chloroform, and propionic acid (6:3:2) were squashed in $1 \%$ acetic-orcein and then observed at 1,000× magnification (Nikon Eclipse 50i, Nikon, Tokyo, Japan). To have solid meiotic chromosome numbers, each figure observed was drawn and photographed. In addition, variations in meiotic chromosome numbers $(n)$ were determined after observations of at least three pollen mother cells per sample. All voucher specimens were identified following Hoshino et al. (2011) and Park et al. (2016), and deposited at the Korea National Arboretum Herbarium (KH) (Table 1).

\section{Results and Discussion}

Observed meiotic chromosome numbers are presented with previous records in Table 1, and representative meiotic chromosome figures are given in Fig. 1. All chromosomes are very short, less than $1 \mu \mathrm{m}$ long, and distinct primary constriction cannot be pointed, which is one of characteristics of holocentric chromosomes (Hipp et al., 2013; Cuacos et al., 2015). Furthermore, bivalents are only observed in all the meiotic chromosomes in the present study.

\section{Carex miyabei $\left(n=43_{\|,}, 44_{\|,}, 45_{\|}\right)$(Fig. 1A) - Sect. Carex}

The meiotic chromosome numbers of the species vary, $n=$ $43_{\mathrm{II}}, 44_{\mathrm{II}}, 45_{\mathrm{II}}$. The counts are incongruent with previous reports from Korean populations, $2 n=66,72$ (Chung and Im, 2018), $2 n=84$ (Chung et al., 2018); and a Japanese population, $2 n$ $=90$ (Tanaka, 1948). The species has been considered as a Japanese endemic, but recently distributions of the species in Japan and Korea have been known (Im et al., 2008; Hoshino et al., 2011; Park et al., 2016). Although C. miyabei is distinctly characterized pubescent perigynia with long beaks, and pistillate scales with aristate apexes, the species has been often confused with $C$. glabrescens (Kük) Ohwi for similarity on female spike numbers (more than two), and sharing ecological habitats (Im et al., 2008). These species occur throughout South Korea, but the latter grows mainly middle parts of South Korea (Park et al., 2016). Because both favor sunny, sandy places along rivers, it is not hard to find populations of the two taxa close each other (Im et al., 2008; Park et al., 2016). Variations in morphological characters such as perigynium shapes and surface features have made it hard to distinguish them from each other. Chromosome numbers of $C$. glabrescens have not been reported. As proposed in the previous studies (Chung and Im, 2018; Chung et al., 2018), taxonomic and cytological research should be conducted to understand the two morphologically challenging taxa in the section with taxon sampling covering the distribution areas of the taxa.

\section{Carex metallica $\left(n=30_{\|}\right)$(Fig. 1B) - Sect. Hymenochlaenae}

The meiotic chromosomes of $C$. metallica from a Korean population is observed for the first time, $n=30_{\text {II, }}$ which is identical to a previous report from Japan (Hoshino et al., 2011). The species only occurs in Jeju Island, South Korea and is mainly distributed in southern parts of China and Japan (Park et al., 2016; Chen and Zhang, 2018; Masaki, 2018). Dai et al. (2010) reported distributions of the species in Fujian (China) and Taiwan. The Hymenochlaenae comprised of about 60 species in Africa, Asia, and Central and North America, and Europe, and many Asian species exhibit narrow distribution patterns (Dai et al., 2010). Thirteen taxa out of fifteen Chinese 


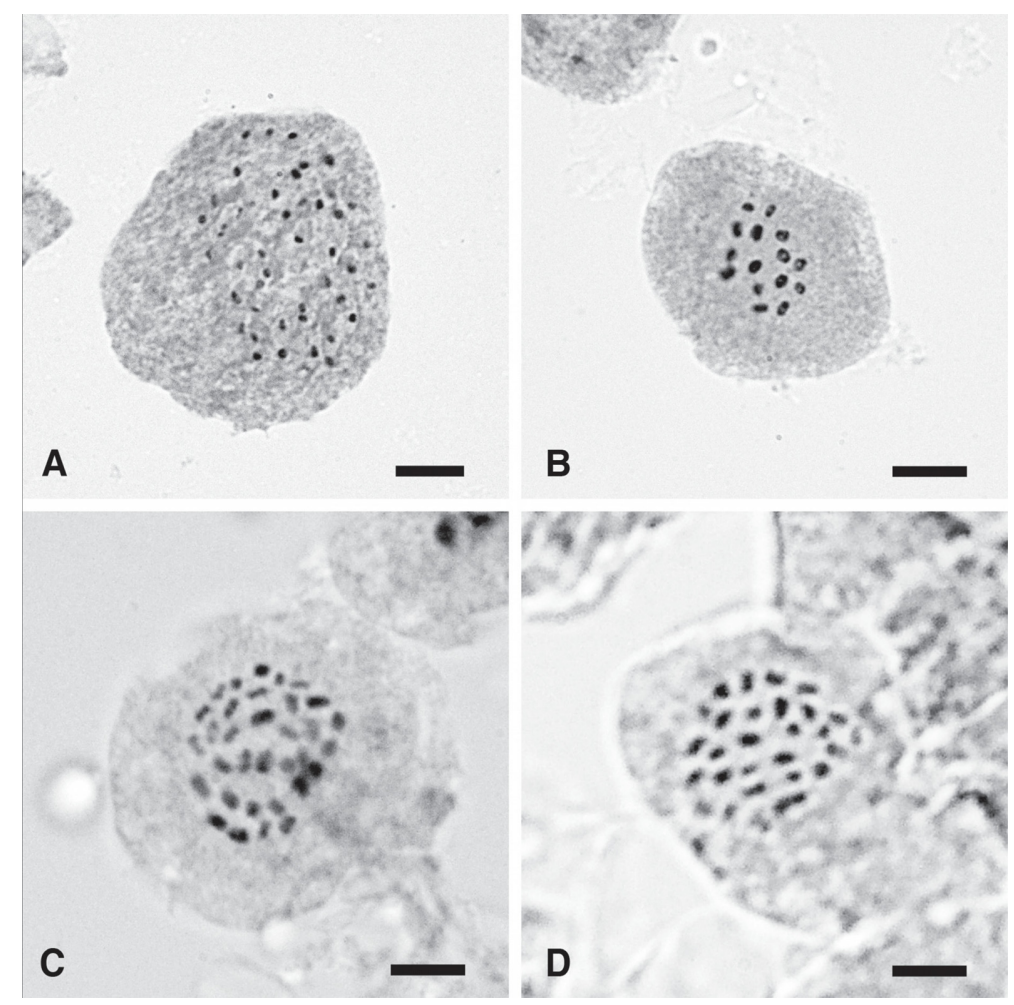

Fig. 1. Photomicrographs of Carex meiotic chromosomes. A. C. miyabei $\left(n=43_{\mathrm{II}}\right.$, Chung 6077). B. C. metallica $\left(n=15_{\mathrm{II}}\right.$, Chung 5150$)$. C. C. fernaldiana $\left(n=33_{\text {II }}\right.$, Chung 6048-1). D. C. appendiculata $\left(n=27_{\text {II }}\right.$, Chung 6070). Scale bars $=5 \mu \mathrm{m}$.

species in the section are endemic to China, and C. hondoensis Ohwi occurs only in Japan (Dai et al., 2010; Hoshino et al., 2011).

\section{Carex fernaldiana $\left(n=33_{\|}\right)$(Fig. 1C) - Sect. Mitratae}

Chromosome number of $n=33_{\text {II }}$ for $C$. fernaldiana is identified, which is the first report on the taxon from a Korean population. In Japanese populations, the species exhibits a range of chromosome number variations, $2 n=66-74$ (Tanaka, 1948; Hoshino et al., 2011). Although the species is distinguished from closely related taxa such as $C$. stenostachys Franch. et Sav. and C. polyschoena by long rhizomes and glabrous perigynia (Park et al., 2016; Nam, 2017), C. fernaldiana is considered as a synonym of $C$. pisformis Bott (Govaerts, 2019). Govaerts (2019) lists homotypic names of C. fernaldiana: C. sachalinensis var. fernaldiana (H. Lév. \& Vaniot) T. Koyama, C. pisiformis var. fernaldiana (H. Lév. \& Vaniot) T. Koyama, and $C$. sachalinensis subsp. fernaldiana (H. Lév. \& Vaniot) $\mathrm{T}$. Koyama. Nomenclatural synonyms need to be reevaluated. The evaluation should be conducted along with examinations on taxonomic synonyms covering the distribution areas of $C$. fernaldiana and C. pisiformis complex.

\section{Carex appendiculata ( $n=27_{\|}$) (Fig. 1D) - Sect. Phacocystis}

For the first time, chromosome number of $C$. appendiculata from a Korean population is revealed, $n=27_{\mathrm{II}}$. Previously, $2 n$ $=76$ and c. 80 were reported from Russia (Krogulevich, 1976; Zhukova and Petrovsky, 1976). The species is mainly distributed in northern areas of South Korea and is characterized with 1-2 terminal female spikes and broad perigynia (Park et al., 2016). Although taxonomic status and delimitation are not congruent among distributed countries, the species occurs in China (north east), Japan (north), Russia (east), and Korea (north) (Dai et al., 2010; Hoshino et al., 2011, Ji, 2013; Park et al., 2016; Chen and Zhang, 2018; Masaki, 2018).

Counts on three taxa are the first reports from Korean populations: Carex appendiculata (Trautv. \& C. A. Mey.) Kük. $\left(n=27_{\text {II }}\right), C$. fernaldiana H. Lév. \& Vaniot $\left(n=33_{\text {II }}\right)$, and $C$. metallica H.Lév. $\left(n=15_{\text {II }}\right)$. The reports on the other species increase a range of variation in chromosome number within a taxon: C. miyabei Franch. $\left(n=43_{\mathrm{II}}, 44_{\mathrm{II}}, 45_{\mathrm{II}}\right)$. The counts confirm that chromosome number variations within and/or among taxa resulted from aneuploidy/agmatoploidy, and connote high species diversity in Carex. The report updates 
chromosome number inventory on Korean Carex to 24 taxa out of 180 taxa. Accumulating chromosome number data in Carex contributes to understanding species diversity of the genus.

ORCID: Kyong-Sook CHUNG https://orcid.org/0000-00024464-4698; Hyoung-Tak IM https://orcid.org/0000-0002-63336244.

\section{Acknowledgments}

We thank Dr. Takuji Hoshino and Tomomi Masaki (Okayama University of Science) for suggestions on chromosome experiments and observations.

\section{Conflict of Interest}

The authors declare that there are no conflicts of interests.

\section{Literature Cited}

de Azkue, D. and A. Martĩnez. 1990. Chromosome number of the Oxalis tuberosa alliance (Oxalidaceae). Plant Systematics and Evolution 169: 25-29.

Chen, W. and S. Zhang. 2018. Species Catalogue of China. Vol. 1. Plants. Spermatophytes (II). Angiosperms (Arecaceae-Poaceae). Science Press, Beijing. Pp. 50, 72. (in Chinese)

Chung, G. Y. and Y. S. Kim. 1997. Study on the somatic chromosome numbers of Korean Aster L. and its allied taxa. Korean Journal of Plant Resources 10: 292-299.

Chung, K.-S. and H.-T. Im. 2018. Meiotic chromosome numbers of five Carex taxa in Korea (Cyperaceae). Korean Journal of Plant Taxonomy 48: 201-205.

Chung, K.-S., A. L. Hipp and E. H. Roalson. 2012. Chromosome number evolves independently of genome size in a clade with nonlocalized centromeres (Carex: Cyperaceae). Evolution 66: 2708-2722.

Chung, K.-S., T. Hoshino, T. Masaki and H.-T. Im. 2017. Cytological investigations on eight Carex species in Korea (Cyperaceae). Cytologia 82: 329-334.

Chung, K.-S., T. Hoshino, T. Masaki, H.-T. Im and S.-J. Ji. 2018. Chromosome counts of six Korean Carex species (Cyperaceae). Cytologia 83: 229-233.

Chung, K.-S., T. Hoshino, T. Masaki, J. C. Yang and H.-T. Im. 2016. Cytological studies on seven species of Korean Carex (Cyperaceae). Cytologia 81: 143-147.

Chung, K.-S., J. C. Yang and Y.-M. Lee. 2013. Chromosome numbers of Carex section Siderostictae from Korea populations
(Cyperaceae). Korean Journal of Plant Taxonomy 43: 22-26.

Cuacos, M., F. C. H. Franklin and S. Heckmann. 2015. Atypical centromeres in plants: what they can tell us. Frontiers in Plant Science 6: 913.

Dai, L., S. Liang, S. Zhang, Y. Tang, T. Koyama and G. C. Tucker. 2010. Carex Linneaus. In Flora of China: Acoraceae through Cyperaceae. Zhengyi, W., P. H. Raven and H. Deyuan (eds.), Missouri Botanical Garden Press, St. Louis, MO. Pp. 285461.

Davies, E. W. 1956. Cytology, evolution and origin of the aneuploid series in the genus Carex. Hereditas 42: 349-365.

Escudero, M., A. L. Hipp, M. J. Waterway and L. M. Valente. 2012. Diversification rates and chromosome evolution in the most diverse angiosperm genus of the temperate zone (Carex, Cyperaceae). Molecular Phylogenetics and Evolution 63: 650-655.

Global Carex Group. 2015. Making Carex monophyletic (Cyperaceae, tribe Careiceae): a new broader circumscription. Botanical Journal of the Linnean Society 179: 1-42.

Govaerts, R. 2019. World Checklist of Cyperaceae. Facilitated by the Royal Botanic Gardens, Kew. Published on the Internet. Retrieved Sep 23, 2019, available from http://wcsp.science.kew.org/.

Guerra, M. 2008. Chromosome numbers in plant cytotaxonomy: concepts and implications. Cytogenetic and Genome Research120: 339-350.

Hipp, A. L., M. Escudero and K.-S. Chung. 2013. Holocentric chromosomes. In Brenner's Encyclopedia of Genetics. 2nd ed. Vol. 3. Maloy, S. and K. Hughes (eds.), Elsevier, New York. Pp. 499-501.

Hipp, A. L., P. E. Rothrock, R. Whitkus and J. A. Weber. 2010. Chromosomes tell half of the story: the correlation between karyotype rearrangements and genetic diversity in sedges, a group with holocentric chromosomes. Molecular Ecology 19: 3124-3138.

Hoshino, T. 1981. Karyomorphological and cytogenetical studies on aneuploidy in Carex. Journal of Science of the Hiroshima University, Division 2, Series B 17: 155-238.

Hoshino, T., T. Masaki and M. Nishimoto. 2011. Illustrated Sedges of Japan. Heibonsha Ltd., Publishers, Tokyo. Pp. 324, 326, 340, 486, 512, 778.

Im, H.-T., K.-S. Kim and B.-U. Oh. 2008. Carex miyabei Franchet. (Cyperaceae) and its distribution in Korea. Korean Journal of Plant Taxonomy 38: 539-545. (in Korean)

Ji, S. J. 2013. A systematic study of the genus Carex sect. Phacocystis (Cyperaceae) in Korea. PhD dissertation, Chungbuk National University, Cheongju, 197 pp. (in Korean)

Kim, S.-Y. 2006. Establishment of chromosome D/B and molecular cytogenetic analysis of Korean native plants. PhD disser- 
tation, Chungnam National University, Cheongju, 169 pp. (in Korean)

Krogulevich, R. E. 1976. Rol poliploidii v genesise flory Putorana. In 1976 Flora Putorana: Materali k Poznaniiu Osobennostei Sostava i Genezisia Gornykh Subarkticheskikh Flor Sibir. Novosibirsk. Malyshev, L. I. (ed.), Nauka, Novosibirsk. Pp. 217-235.

Lee, J. and S. Y. Kim. 2008. Chromosomes of Endemic Plants in Korea 2008. Korea Research Institute of Bioscience and Biotechnology, Daejeon, 75 pp.

Luceño, M. and M. Guerra. 1996. Numerical variations in species exhibiting holocentric chromosomes: a nomenclatural proposal. Caryologia 49: 301-309.

Masaki, T. 2018. Distribution Maps of Carex (Cyperaceae) in Japan. The Japanese Society of Cyperology, Okayama. Pp. 426, 427, 451,724, 754. (in Japanese)

McArthur, E. D. and S. C. Sanderson. 1999. Cytogeography and chromosome evolution of subgenus Tridentatae of Artemisia (Asteraceae). American Journal of Botany 86: 1754-1775.

Nam, G.-H. 2017. A systematic study of the genus Carex sect. Mitratae (Cypearaceae) in Korea. PhD dissertation, Andong National University, Andong. Pp. 144-145. (in Korean)

Park, S.-H., Y.-M. Lee, H.-J. Kim, J.-C. Yang, C.-S. Jang, K.-H. Lee, J.-S. Lee, J.-S. Han, H.-J. Kim, K.-S. Jeong, D.-C. Son, D.-H. Lee, M.-J. Joo, E.-M. Sun, C.-H. Shin, K. Choi, S.-H. Oh, K. S. Chang, S.-Y. Jung and S.-J. Ji. 2016. Illustrated Cyperaceae of Korea. Munyoungsa, Seoul. Pp. 10, 23-38, 96, 180, 182, 220, 292 3, 102, 220, 284, 282, 334.

Peruzzi, L., I. J. Leitch and K. F. Caparelli. 2009. Chromosome diversity and evolution in Liliaceae. Annals of Botany 103:
459-475.

Rice, A., L. Glick, S. Abadi, M. Einhorn, N. M. Kopelman, A. Salman-Minkov, J. Mayzel, O. Chay and I. Mayrose. 2015. The Chromosome Counts Database (CCDB): a community resource of plant chromosome numbers. New Phytologist 206: 19-26.

Rockinger, A., A. Sousa, F. A. Carvalho and S. S. Renner. 2016. Chromosome number reduction in the sister clade of Carica papaya with concomitant genome size doubling. American Journal of Botany 103: 1082-1088.

Rothrock, P. E and A. A. Reznicek. 1996. Documented chromosome numbers 1996:1. Chromosome numbers in Carex section Ovales (Cyperaceae) from Eastern North America. Sida 17: 251-258.

Rothrock, P. E., A. A. Reznicek and A. L. Hipp. 2009. Taxonomic study of the Carex tenera group (Cyperaceae). Systematic Botany 34: 297-311.

Tanaka, N. 1948. The problem of aneuploidy (Chromosome studies in Cyperaceae, with special reference to the problem of aneuploidy). Biological Contribution in Japan 4: 1-327. (in Japanese)

Windham, M. D. and G. Yatskievych. 2003. Chromosome studies of Cheilanthoid ferns (Pteridaceae: Cheilanthoideae) from the western United States and Mexico. American Journal of Botany 90: $1788-1800$.

Zhukova, P. G. and V. V. Petrovsky. 1976. Chromosome numbers of some Western Chukolka plant species, II. Botanicheskii Zhurnal (Moscow \& Leningrad) 61: 963-969. 